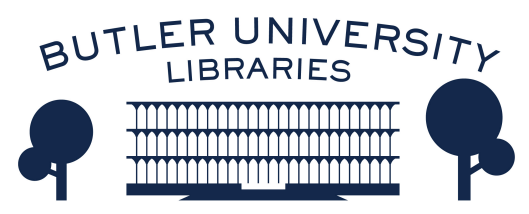

Journal of Hindu-Christian Studies

Volume 28

Article 10

2015

\title{
Viewpoint: For the Love of Complexity: Educating Beyond Enthusiasms
}

Thomas A. Forsthefel

Mercyhurst University

Follow this and additional works at: https://digitalcommons.butler.edu/jhcs

\section{Recommended Citation}

Forsthefel, Thomas A. (2015) "Viewpoint: For the Love of Complexity: Educating Beyond Enthusiasms," Journal of Hindu-Christian Studies: Vol. 28, Article 10.

Available at: https://doi.org/10.7825/2164-6279.1609

The Journal of Hindu-Christian Studies is a publication of the Society for Hindu-Christian Studies. The digital version is made available by Digital Commons @ Butler University. For questions about the Journal or the Society, please contact cbauman@butler.edu. For more information about Digital Commons @ Butler University, please contact digitalscholarship@butler.edu. 


\title{
Viewpoint: For the Love of Complexity: Educating Beyond Enthusiasms
}

\author{
Thomas A. Forsthoefel \\ Mercyhurst University
}

I'D like to begin this essay by sharing a brief personal narrative which I trust is illustrative. I was raised in the Roman Catholic tradition, but like many students in college ignored or rejected much of it in favor of other worlds of meaning and value. However, late in my undergraduate career, at Georgetown, I found myself in net of emotional and spiritual distress and felt existentially unmoored. That distress was the antecedent and catalyst for a profound re-encounter with the heart of Christian faith, a conversion or, perhaps better, re-conversion, as my faith certainly was meaningful to me as a young boy growing up in a traditional Catholic household. Nevertheless, this later breakthrough was stimulated by an oldfashioned encounter at a Southern Baptist church, replete with altar calls, witnessing, and confessing with one's lips that Jesus is Lord to attain certain salvation.
After that happened, I naturally became mildly annoying to my brothers and sisters, who were bemused by my intensity and frankly thought I was a little off my rocker. And yet, I felt a clarity and certainty of conviction; I felt that I knew things, and a deep psychological and cognitive resolution ensued. I saw things clearly. I was on fire with faith. I returned to Georgetown, joined an evangelical fellowship, sang hymns, passed out Bibles, witnessed to Jesus, and took as a model of intensity and passion my roommate Patrick, a former Catholic, who once made an appointment with the President of Georgetown at that time, the Jesuit priest Father Timothy Healy, and asked him right then and there if he would pray with him and accept Jesus in his heart and thus be saved.

All of this was well and good. Until something happened. I had left the School of

Thomas A. Forsthoefel is professor of Religious Studies at Mercyhurst University specializing in Indian religion and philosophy. He has written, edited, or co-edited four books: Knowing Beyond Knowledge (2002), a study of the cognitive dimension of religious experience in classical and contemporary Advaita; Gurus in America (2005), edited with Cynthia Ann Humes, which considers the social and philosophical negotiations that obtained in the migration of Hindu gurus-or their ideas-to America; Soulsong: Seeking Holiness, Coming Home (2006), a cross cultural exploration of holiness and human flourishing, and The Dalai Lama: Essential Writings (2008), an edited collection of principal philosophical, ethical, and meditation teachings of the Dalai Lama. He is currently working on a project, Praying with the Poets, which engages poetry of the sacred in the world's religions. 
Foreign Service, transferred to the College of Arts and Sciences, and became an English major. At the same time, I took numerous Theology courses, nearly earning a second major as well. Literature, if anything, deals with the roiling complexity of human experience, the raw data of human living. And theology introduced me to a systematic examination of the content of faith, a faith that didn't spring up a day and a half ago. So, after a year of intensive course-work in these two disciplines, I found myself calling into question the tidy certainties of fundamentalism and its black-and-white view of the universe. Such a categorical or epistemological approach to the world could not hold up for me in the face of reasoned reflection on human experience, with its complexity, often vexing, and bewildering ambiguity. Something had to give. In the end, at that time, I found myself re-appreciating the faith in which I was raised, which, despite its own history of stark judgment and exclusion'extra ecclesiam nulla salus' quickly comes to mind-nonetheless was and is a community that takes seriously the life of the mind, applying the canons of reason to the content of faith. In the end, I returned to sacramental life of the Church, a faith rejuvenated by a spiritual experience triggered in a non-Catholic Christian context and then soon fleshed out and informed by systematic study and reflection.

What happened? I got educated. Or, more precisely, through the content and method of academic investigation, I began to see far greater nuance, more grey than black and white, and histories and contexts which cannot but complexify things; I gradually saw also that other more complex motivations and conditions became clear in any religious tradition as well-power formations, control, sexism, patriarchy, homophobia, etc. I learned that intellectual honesty required jettisoning concepts that were inadequate, faulty, incoherent, or inhumane. And that honesty also required courage, too, by publicly articulating critical reflection and challenging the stock set assumptions of a particular subculture or tradition. I recall, after giving a talk to the evangelical fellowship to which I belonged and challenging a host of simplicities and certitudes of the group, my best friend, who came to the meeting only to hear my talk, said, "Looks like you skewered a few sacred cows in there." And of course he wasn't referring to Hinduism at all, but the manner in which certain content in any religious tradition somehow becomes inviolable to scrutiny, reasoning, reflection, and criticism. By the time I graduated from Georgetown, I had returned to a more informed Catholic faith; soon afterward I went to India to serve as a lay volunteer, and that intense, powerful year further de-stabilized tidy categories of faith, opening me to other dimensions of religions and religious experience. Without being overly reductive, it is safe to say that the seed of my vocation as a scholar of religion took root in my theological training at Georgetown and then germinated in India.

Let me briefly explain. While in India that first time many years ago, two Catholic models of inter-religious and cultural engagement deeply impressed me, with measures of dismay, on the one hand, and encouragement on the other. I served as a volunteer in a mission led by the Dutch Salesian, Fr. Francis Schlooz (d. 1998), already in India fifty years by the time I arrived there. He was a tornado of energy, always afire with schemes to help the poor, and 
typically worked through the entire night once a week, drinking his coffee sweetened with condensed milk and responding to donors in Europe and North America. I was deeply impressed by his generosity and vigor, which was barely slowed by a moderate but chronic case of elephantiasis. And yet, one day at lunch he recounted a story about visiting an ill church member in the hospital. Before arriving to his room he passed the maternity ward, saw a baby resting in a crib, leaned over, sprinkled some water, and said, "I baptize you, Don Bosco, in the name of the Father, Son, and Holy Spirit. There, Lord, I got one for you!" I was taken aback by this and frankly didn't know what to say. My training with the Jesuits at Georgetown offered an altogether different model of understanding the relationship obtaining between religions. Indeed, I profited immensely from a sustained study of Karl Rahner, and so I was familiar with-and appreciated-the theory of the anonymous Christian. While perhaps presumptious-why aren't we all anonymous Krishna devotees, as the Gita (9.23) suggests? Or anonymous Buddhists, owing to buddhanature?-the theory was nevertheless an attempt to move away from extra ecclesiam nulla salus and, from the framework of Christian theology, offer a constructive model of inclusivity. To my dismay, Fr. Schlooz's clandestine baptism implied an affirmation of the earlier exclusivist model and in fact matched the same high stakes dichotomy in my own flirtation with fundamentalism.

The inclusivist model, however, was affirmed by a second example in India, that of Bede Griffiths. Upon the urging of Fr. Schlooz, I travelled to Shantivanam, participated in the ritual and meditative life of the ashram for ten days or so, and had an opportunity to have a private audience with Fr. Griffiths. During the course of that conversation, I was struck by his warmth, humility, and intellectual curiosity and vigor. He asked what I read at Georgetown; when I mentioned that Rahner was a rich and seminal focus in a favorite theology seminar, he immediately responded, "I find Rahner answers many of my questions." The example of a gracious, graceful, and gentle man, continually engaging and wrestling with the complex and difficult questions, even in advanced years, was altogether impactful both in terms of substance and style. I had gone to India to detach from culture, family, and, to some extent, religion, in order to gain greater self-understanding, but layered in that agenda was a hidden question of vocation. I suppose, most simply, I was exploring the possibility of a missionary vocation. What I realized, over time, was that my vocation, in part stimulated and affirmed by the example of Bede Griffiths, was much more reflective and contemplative, rather than activist, at least as expressed in the model of Fr. Schlooz. When I decided on doing graduate studies in religion, I immediately knew the area I wanted to focus on-Hinduism and Indian religions-and the approach to it: philosophical, theological, comparative.

Recently, I had a conversation with one of my Jesuit mentors from Georgetown. When I told him about my intense, brief infatuation with fundamentalism as an undergraduate, he calmly mentioned, almost as an aside, that it was "developmentally appropriate." That observation is worth exploring here. Most of us who have children know that it is typically difficult- and sometimes inappropriate-to engage children, even teenagers, in discussions over issues that are emotionally charged and 
fraught with complexity, especially when children's identifications are threatened. Divorce and its bewildering tendencies-for adults, let alone for children-is perhaps paradigmatic. Developmentally, children are ill-equipped with the capacity to negotiate the complex emotional and psychological textures of relationship that can issue in its breakdown. And yet, owing to intensely high personal stakes and a need to make sense of a confusing array of phenomena, children sometimes slap on flat, black-and-white categories, simplistically reducing one or both partners in dualistic terms: a good guy and a bad guy. However, increasingly refined moral reasoning, greater life experience, and increased selfawareness often loosens the tight lid on such dualistic thinking; a greater awareness and appreciation of complexity emerges, marked by increased ease with ambiguity and mystery, and, as a result, some of the more volatile reactivity may be attenuated.

In the usual course of the things, all parents, even those of intact families, are humbly revealed in their humanity; we are not perfect, we make mistakes, and we all, whether parents or not, are constellations of gifts, flaws, virtues, neurosis, self-sacrifice and selfishness. As parents, however, the difficult truth is that we disappoint our children, at least sometimes; regardless of the fact that such disappointment becomes a crucial psychological or spiritual learning curve for children, it is nonetheless painful. The idealized parent does not square with reality, creating a considerable emotional and cognitive challenge for the child. Clinging to a false ideal-and therefore failing to accept the truth of complexity-becomes a breeding ground for neurosis. Maturity requires, in the end, a greater acceptance of what is, a reality whose sharp dualisms are subverted; what emerges is a kind of non-dualism which sees streams and currents in human phenomena, causes and conditions, complexity and interconnection, all joined with the possibility of finally accepting them without reactive judgment.

These examples illustrate a familiar developmental approach to cognitive maturity, one with a long history in psychology. The relevant analog here is this: most undergraduates, especially those fresh from high school, are only just beginning to stretch their categories that make sense of the world. At the same time, anyone, whether undergraduate or not, can have a particular encounter with an alternative world view that destabilizes their standard assumptions, offers a breakthrough to new horizons of meaning or purpose, captures their imagination, and animates their hearts and minds. This sometimes happens, and is not at all uncommon, in the non-Western religions classes I teach, though it can certainly happen in other courses as well. Indeed, when I ask students why they take the class, a number of students typically lament a vacuity which they've experienced in the religion of their upbringing-an emptiness or an existential incoherence; it appears their home tradition has failed them in significant ways. And yet some students clearly are on a spiritual quest, keenly searching for richer meaning and purpose, and they find themselves drawn to Eastern religions in part to meet or express that need. Just as children painfully learn that parents can disappoint, in this case, some students learn that religious traditions can be painfully disappointing as well. However, in the 'first fervor' of their encounter with 
Eastern religions, they may also slip into dualistic thinking, idealizing the new tradition: Eastern Religions are 'mystical', spiritual, liberating; Western religions are dry, oppressive, more concerned with power and wealth than genuine spiritual well-being. The reductio is, simply and simplistically: Eastern Religions-good; Western Religions-bad. Such predication may not be tacitly expressed, but it is often seen in students' sweeping generalizations: Eastern religions are 'better;' they have their acts together; they are more spiritually evolved. Western religions do not and are not. At best, Western religions are outdated; at worse they demonstrate the most wretched forms of oppression. Frustrated or exasperated with a Christianity that does not work for some students-viewed as hierarchical, patriarchic, homophobic, sexist, and controlling-Hinduism and Buddhism, expressing grand spiritual visions in fresh idioms and philosophical perspectives, can become compelling for some students. This is a good thing. The encounter with religions of India can become a heuristic which has the potential to generate profound insights in the student's understanding of the world and their own self-understanding; such is a worthy and constructive outcome, if ancillary to primary course objectives.

However, I would add that that attraction owes also to the fact that "Eastern Religions", are "different," at least in a prima facie way, and part of young adult development precisely includes the importance of differentiation. The need to establish an independent, authentic self requires a healthy differentiating of oneself from parental and social forces that overwhelm or even subsume personal identity. Maturity means becoming one's own person, and that in turn means thinking critically about one's emotional, cognitive, cultural, and religious contexts, and in the end, thinking for oneself. We see budding differentiation in our children who come home dressed in unusual clothes or wearing surprising new tattoos. Gravitating to such choices is appealing in part, I suspect, precisely because it is different, sometimes outlandishly so, going against the grain of a conventional model found in family or society. The gesture has value partly because it says, "I am not you. I am different." Similarly, I think the infatuation some students experience with Eastern Religions owes partly to the religions' apparent difference from Western traditions. And, of course, the difference is empirically evident in many and significant ways. The emptiness doctrine is not the doctrine of the Holy Trinity. Nor is the Holy Trinity the Trimurti, a point which becomes a predictable classroom challenge each semester. Yet, while an appropriate course approach to the study of the world's religions is to meet the traditions on their own terms, humans are also creatures of comparison; so, to recognize significant differences while also noting general patterns found in the world's religions is entirely appropriate, too. Just how to do that-skillfully and well-is the rub, as the extensive debates on method in the history of religions indicate.

Nevertheless, an irony emerges. Some students may be disenchanted with Western traditions for their untoward histories and many problems, and gravitate to India or East Asia enamored with a new ideal. However, on very human levels of organization and practice, Hinduism and Buddhism of course have also been beset in their long histories with the same troubling permutations as Christianity or any other religion-e.g., sexism, homophobia, and 
patriarchy, nor have they escaped the controlling tendencies that tend to appear in the empirical record of most organized religions.

I take it as part of my vocation as professor to address these ironies, to introduce and unpack the real-world complexity of the religious traditions, that is, to present the whole picture, or at least a broader perspective of on-the-ground empirical phenomena. As one who values philosophical introspection, I am happy to have students wrestle with or engage the Upanishads; however, it is not useful to present them as rarefied "Himalayas of the Soul" (as the backcover of Juan Mascaro's selected translation does) or to present a Hinduism purely in abstract and idealized terms. That's not reality. Just as individuals and relationships are complex and escape tidy categorization, so human institutions are similarly and inevitably marked by complexity, including social constructions marked by power formations, hidden agenda, the need for control, etc. In short, part of my classroom task is to destabilize students' overly tidy-or even lazy-conceptualizations and to introduce them to nuance and complexity in the histories of religions. This is not to crush the dreams of students enchanted with the 'mysticism' of India and who have discovered something potent, charged with value and purpose. Nor is it to mute the passion of a student who's on fire with a new faith. Naturally, I'm deeply sympathetic with that, remembering my own process long ago. Moreover, despite the troublesome issues and disturbing historical record found in most religious traditions at times, I remain convinced of religions' overall positive contribution-all things considered-to human flourishing and their ongoing potential to contribute further to it.

However, it would be a failure on my part were I to ignore or gloss over the bigger picture, skipping the contradictions, absurdities, dubious ethics and politics which seem to escape no religion. Yet, in concert with the intellectual virtue at the root of this vision is the importance of practical virtue, too: a requisite of wisdom vis a vis students that includes or comprehends generosity, kindness, patience and detachment. Students, as all of us, are on a path, one marked by process and development. It does no good to clobber them with an arrogance of knowledge in the service of ego; indeed, I've seen colleagues do this to students and have also seen the anger and resentment it causes in them. Such useless chest-thumping is empty of any real service or value to students. Presumably, an academic introduces complexity, but to hammer a student subverts that goal by a reductive egotism. It's no wonder that the Buddha held, "greed for views tend not to edification," when views-philosophical, academic, theologicalbecome transparent extensions of self. In the end, part of our contribution in the field lies not just with our scholarly achievements but by the example we set in the classroom-certainly of thoughtful and critical inquiry, but done in an atmosphere marked by patience, kindness, and generosity toward our students' own intellectual and developmental processes.

In the case of divorce, a wise parent may simply, yet painfully, bear with simplistic black-and-white conceptualizations of their children, knowing that time in the end will soften them. The child isn't ready or equipped to handle the dissolution of the ideal in the confrontation with the real. College students 
are more equipped to engage such complex processes, but, as we know, there is a significant difference between the analytical skills of freshmen and seniors, and, in any case, youthful idealism has a strong hold. Appreciating the passion and intensity of students, we use the tools of scholarship and the passion which we feel for our disciplines to include-to borrow from Rudolf Otto-both the 'fascinating' or attractive aspects of all religions as well as the 'tremendous' aspects, which here is perhaps less 'awe-inspiring' than off-putting, dreadful, problematic, and certainly, complex. And reality is complex.

Buddhist sensibilities offer a pedagogical heuristic. If a goal of proper education is to complexify things, we might see how Buddhism might be helpful here. On the one hand, we might draw from a theory of projection, which certainly is not exclusive to Buddhism, but nonetheless has been neatly explained, for example, in the teachings of the Dalai Lama and other contemporary Buddhist teachers. On this take, owing to presumed needs of 'self', we gravitate to something that we want, inflating the presumed good qualities, ignoring flaws or limitations. The classic example of this is found in amorous relationship. Through 'rosy', or, in this case, self-centered lenses, lovers tend to inflate the positive qualities of their partners owing to need and desire, ignoring or dismissing the putative 'negative' qualities. The subject, owing to 'self', fails to see the whole picture, as it were, i.e., a truer, more complete reality 'as it is'. When that picture inevitably changes-i.e., when the subject now 'sees' the flaws-the 'perfect' match is now less than perfect; unless the whole person is loved as he or she is, not as he or she is perceived, the disenchanted partner may terminate the relationship. But nothing has fundamentally changed in the object of perception. That person remains the same. Of course, what has changed is the perception of the subject, whose desire is now muted by the putative flaws seen in his partner.

A similar infatuation happens with student romance with the 'mystical East'. Some students, abuzz with potent ideas and inspiration, inflate the presumed positive qualities of Indian or Asian religions, failing to see or take account of the difficult, conflicted, or problematic elements in the traditions. I understand my job as helping them see the bigger picture, to regard honestly the complex mix of virtue and flaw in Eastern religions as in any other religion. I'll address sexism in India. I'll have students read the Code of Manu or texts on stri dharma. Or I'll have students read sexist and objectifying words supposedly made the Buddha. Such strategies aim to make real a complex phenomenon, and, truth be told, attempt to pop the balloon of students' projections. Hinduism's historical products do not just include the "Himalayas of the Soul," but the Artha Shastra and its shrewd political machinations, certainly on par with the most sober or even cynical exposition found in Machiavelli. Hinduism boasts of exalted temple architecture replete with a staggering array of symbols which encode multi-valent theologies. But not infrequently, these symbols also reveal the medieval intersection of religion and politics and demonstrate real-world power formations, too; legitimating-by art, sculpture, word or song-royal courts which endowed temples and in turn validated and supported Brahmin religious and social ideological formations. 
Similarly, Buddhism is not 'peaches and lite', although often the only 'operative' images or impressions some students have of Buddhism is the laughing Buddha or even the Dalai Lama, who himself does seem to convey an infectious joy. But that joy owes at least in part to intense spiritual practice and many years of rigorous scholastic training to support that practice as much as it may owe to personal temperament or brain chemistry. The laughing Buddha also has its counterpart in the early images of the emaciated Buddha, too, or the frightening terrific deities of later Buddhist iconography. Whether with Hindu or Buddhist materials-or those of any religion-students need to ground the ideal with the real, and by encountering and confronting these dualisms, eventually transcend them in an ultimate acceptance of a non-dual whole. The light and the dark, the holy and the unholy, the ideal and the real, the sacred and the profane, the good and evil, the rational and irrational. All of these dichotomies are found in the world's religions. In fact, one might say they are constitutive of religions. Any intellectual maturity, let alone spiritual maturity, must come to terms with them.

Again, we may find Buddhist philosophy helpful here as a heuristic. "No soul" doctrine and its later development, emptiness doctrine, tell us that all phenomenal events are void of isolatable, invariant, independent marks. A
Buddhist approach to reality eschews any single, exclusive, definitive essence, preferring instead complexity, flow, inter-relationship. Phenomenal events cannot be captured in ultimate, reductive black-and-white categories. Reified or 'concrete' conceptualizations are eschewed in favor of fluidity, complexity, and causal connection. Categorical or dualistic notions are subverted ultimately in a non-dual whole. As Thich Nhat Hanh explained in his commentary on the Heart Sutra, as we look upon the rose, we also 'see' the garbage. As we look upon the garbage, we 'see' the rose. The reality is whole, one. Similarly, intellectual honesty requires that we introduce the students to the 'whole picture' in their dynamic encounters with the world's religions. While the 'rose' is there-the saints, heroism, and selfsacrifice seen in religions-we must also present the 'garbage', as well, registering complex social and political formations, untoward histories, absurdities and immoralities, helping students to engage all of it, the good and the ill, with critical analysis and rational evaluation. In doing so, the student not only gains a truer view of the phenomena of particular religions, freer from his or her idealized projections, but also, in and through that process, may facilitate the transforming of the 'garbage' of religion into its rose. 